\title{
Outspoken Indigenes and Nostalgic Migrants: Maori and Samoan Educating Performances in an Aotearoa New Zealand Cultural Festival
}

\author{
ILANA GERSHON \\ Indiana University \\ SOLONAIMA COLLINS \\ University of Auckland
}

Background/Comtext: Theorists of civil society often view civil society as a site for democratic education. Civil society is supposed to assist democratic practice by offering people contexts in which they practice promoting the common good. This article, following Nin a Eliasoph's intervention, takes this to be a claim requiring ethnographic exploration. The article provides an ethnographic answer to the question, What do people actually tell each other about the common good or national well-being in civil society moments? To explore this question, the authors turn to how a Samoan cultural group and a Maori cultural group rehearse and perform in a citywide high school cultural festival in Auckland.

Purpose: This article compares how migrant high school students and indigenous high school students use performances of traditional songs and dances to explore their relationships to the New Zealand nation. The article examines how the rehearsals take place, particularly who disciplines whom and how different levels of expertise are displayed. The authors compare how tutors circulate knowledge and discipline in the rehearsals with how the students perform their relationships to the New Zealand nation on stage.

Setting: We conducted ethnographic research at two different high schools in West Auckland, New Zealand. 
Population: We observed two cultural groups with approximately 20 high school students in each. We also interviewed approximately 10 teachers and tutors who had been involved in preparing Samoan and Maori cultural groups for this festival.

Research Design: This was a qualitative case study. We observed rehearsals for 8 weeks and conducted semistructured interviews with students and teachers.

Conclusions/Recommendations: The authors argue that through the rehearsals and the performance, the Samoan migrant students and the indigenous Maori students adopt different relationships to the nation. The Samoan migrant students see themselves as more aligned to Samoa as the homeland that few of them have visited. They are out of place in the New Zealand nation and use nostalgic performances to perform this sense of dislocation. The Maori students, on the other hand, use the performances to express a political disenchantment with the New Zealand nation. They are constantly critiquing government policies in the context of these performances. In short, both Samoan and Maori students are expressing the ways in which they do not belong to the nation through their performances.

Every couple of years, a controversy springs up in the New Zealand press concerning the annual ASB Bank Auckland Secondary Schools Maori and Pacific Island Cultural Festival. The festival celebrates indigenous Maori performances and the performances of various migrant groups to New Zealand, especially Pacific Island groups. Every so often, a wellintentioned social critic will find a forum in the public sphere to air his or her concern that this citywide festival encourages academically weak minority students to waste their time on song and dance instead of homework. In 1997-the year I was studying a Samoan group of high school students prepare for the festival-the social critic was David Lange, a former Labour Prime Minister. David Lange was reported as saying on a radio show,

Education is about getting yourself ready to become a parent, a teacher, a worker, an office worker, a computer literate, someone who is able to read and write and express themselves in confidence in the environments they live in. You don't do that by getting dressed up and dancing in the street (New Zealand Herald, March 21, 1997).

His statement sparked a flurry of responses on Maori and Pacific Island radio talk shows and in newspapers. ${ }^{1}$ People in these forums kept telling each other that the festival either strengthens students' cultural identity or damages their chances for future success at selling their labor in the marketplace. ${ }^{2}$ At the heart of this controversy is a concern about the kinds of New Zealand citizens whom schools and their satellite activities are seen as fashioning. Should schools help minority students become 
more cultural, or should schools help minority students become more employable?

Being cultural and being employable need not be antithetical. The divide occurs because of the pragmatic definitions of the cultural and the employable-what people tell each other it means to be cultural or employable in New Zealand. Arguing about this festival is a labor of division, rendering tangible the controversial triangle of cultural citizen, working citizen, and politically engaged citizen. Interestingly, the politically engaged citizen is the missing term in this recurring controversy that surrounds the festival, although to be politically engaged is a goal that David Labaree (1997) has noted haunts every effort at educating citizens in a democratic society. Whereas the public debates might ignore the politically engaged citizen, the rehearsals and the performances in this festival all focus on this missing term. The question of how best to be a citizen of New Zealand looms large when one focuses on the performing cultural groups themselves. As happens frequently, what people are arguing about in this context is only tangentially related to what is being practiced. In this article, I claim that the festival is not in fact producing cultural citizens or employable citizens; it is producing a citizenship with uneasy relationships to the current nation-state and deep longings for other kinds of nations. Preparing and performing in this festival teaches students a critical, ambivalent, and distanced connection to their current political systems. To ask about cultural citizens or employable citizens is to ignore what is at the heart of the festival performances, the democratic citizen.

By arguing that these festival performances are primarily about democratic citizenship, I am offering an ethnographic answer to a longstanding theoretical concern with civil society. I am speaking to Tocqueville's (1838/2000) reformulation of Hegel's vision of civil society. Briefly, Hegel (1821/1967) suggested that civil society is an important site in which the individual meets the social, in which an individual's particular selfish drives are interwoven into a larger social good. Tocqueville took this a step further and argued that civil society is a site in which individuals learn how to be both social and political; in short, civil society becomes a space for democratic education. This vision of civil societythat it is an arena for learning how to be a particular kind of political actor with well-defined opinions-has been more recently articulated by Jürgen Habermas (1989) and by Charles Taylor (2002) in his discussion of social imaginaries. For both Habermas and Taylor, civil society is where people learn and practice how to be politically engaged in a modern democratic fashion. This is a theoretical supposition that calls for ethnographic exploration. What kinds of conversations, political or otherwise, 
do people actually have in public contexts? When people are participating in civil society, what kinds of relationships to larger social orders, such as the nation, are they being taught? ${ }^{3}$ I turn to how Maori and Samoan students practice and perform cultural songs and dances to explore what they are also teaching each other and their audiences about their alignments with the New Zealand nation. ${ }^{4}$

To understand how performing in a festival designed to celebrate cultures instead teaches about citizenship, I need to delineate how ideas of being cultural have gradually emerged as political stances in New Zealand as people try to respond to historical inequities produced by New Zealand's colonial past (Goldsmith, 2003; Webster 1998). Since the 1970 s, Maori politicians and activists have been successful in framing questions revolving around how to govern a culturally plural nation-state in terms of an indigenous critique of Anglo-New Zealand politics. Currently there is a Maori renaissance in New Zealand-visible even overseas in an effervescence of Maori cultural activity that has inspired films such as Whale Rider and novelists such as Keri Hulme, Patricia Grace, and Witi Ihimaera. Various social policies have directly supported the infrastructure that has allowed Maori culture to flourish-Maori community centers, government-sponsored Maori language preschools, Maori radio and television stations, and various Maori-specific housing and welfare programs.

These policies have largely emerged in response to Maori claims for social justice, which have set the tone in New Zealand for defining how one should best respond to political and social inequalities, ensuring that these differences are framed as cultural. In public rhetoric, New Zealand is a multicultural nation masquerading in bicultural clothing. New Zealand is now explicitly described in government literature and the media as a bicultural nation, even frequently referred to as New Zealand/Aotearoa. The never-ending work of nation building is currently presented as tending to the fraught relationship between Maori and Anglo-New Zealanders. In this context, not surprisingly, other cultural presences exist as third terms; those engaged in the project of being other than Anglo-New Zealander or Maori are engaged in a project of otherness indeed. In this article, the locus for this otherness is a Samoan high school cultural group in which students perform the songs and dances of Pacific Islanders who have been migrating to New Zealand since the $1950 \mathrm{~s}^{5}{ }^{5}$

Projects entailing fashioning other cultures are thus variously unsettling in the New Zealand context and, like other unsettling projects, inspire instruction. One public forum for instructing others about cultural difference, and explaining how best to engage with cultural 
difference, is the annual ASB Secondary School Festival of Maori and Pacific Island Performing Arts. This festival frames cultural differences in terms of songs, dances, oratory, and food-in short, cultural difference with the political edge supposedly erased. ${ }^{6}$ As mentioned earlier, controversy periodically emerges surrounding these festivals; they are seen as a problematic distraction for the students who perform in cultural groups. Maori and Pacific Island students are commonly understood to be the low academic achievers in the New Zealand educational ethnoscape. Performing in a cultural group 7 demands that they allocate time to producing song and dance that the festival's critics would prefer was devoted to homework. So the public presentation of cultural diversity as consumable and performable is accompanied by the critique that being trained to be a cultural citizen prevents students from being trained to be laboring citizens.

Although controversy surrounding the festival provides one arena through which to teach what a good citizen of a bicultural (or multicultural) nation should be, preparing for the festival provides another such arena. Through the rehearsals and preparations for the festival, the students are taught how to have a specific relationship to cultural knowledge. This article compares how a Maori cultural group prepares and performs with how a Samoan cultural group prepares and performs. I am interested in how people participating in these cultural groups teach both indigenous and migrant commitments to the New Zealand nation. I argue that the Maori cultural group is shown repeatedly through the pragmatics of rehearsals and public performance how to transform tradition, in the guise of song, dance, and oratory, into a political forum for commenting on the nation. In contrast, those in the Samoan cultural group explain to each other that their allegiances should be uncritically with Samoa. More important than teaching the actual traditions, the leaders and teachers of each group present ways of relating toward the traditional, teaching how to make traditional songs and dances into vehicles for political critiques or to frame a nostalgic nationalism.

The 3-day festival that these cultural groups prepare for has an energized and celebratory atmosphere-its focus is clearly on a singing and dancing citizenry. High schools throughout Auckland send cultural groups to complete on the festival's six stages. Each stage is devoted to a particular minority group-Maori, Samoan, Tongan, Niuean, Cook Island, and one stage devoted to noncompetitive groups such as Chinese, Thai, Indian, and Fijian. Some schools have a team for each stage; others might have only a Maori group, or only a Samoan and Cook Island group. Anyone can be a member of a cultural group, and one does not have to identify as Samoan to be in a Samoan cultural group. Cultural 
groups have a predetermined number of items that they must perform, items that have been agreed upon as traditional. The judges choose the best teams in each category, which then determines the best overall teams. Some schools have reputations as the schools to beat. The same three Samoan cultural groups had won 5 years in a row when I was doing research: Auckland Girls Grammar, McAuley High School, and De La Salle College. For some in the audience, the only suspense revolved around which of the three teams the judges would select to be first, second, or third.

\section{HISTORICAL BACKGROUND}

Discussions of what it means to have a culture are framed in New Zealand by the historical interactions between the indigenous Maori and the British colonial settlers and their descendants. The British began actively colonizing New Zealand in the 1830s, much to the displeasure of the many Maori tribes already there. In 1840, Lieutenant-Governor Hobson began encouraging Maori chiefs to sign the Treaty of Waitangi in an attempt to thwart rival French claims to antipodeal trade and land. The treaty promised that the British Crown would protect Maori and their treasures in exchange for sovereignty over New Zealand-the precise definition of sovereignty and what constitutes a Maori treasure becoming a heated topic of debate ever since. Approximately 500 chiefs signed the treaty. For the next 100 or so years, the British settlers (from here on out, Anglo-New Zealanders) disregarded this treaty whenever convenient in a style familiar to scholars of colonialism. The Anglo-New Zealanders told each other and Maori that Maori were savages in need of a civilizing mission. They described Maori as requiring instruction on how to use land, how to participate in a market, and how to be moral. It was often the government's responsibility, along with the church, to provide the opportunities for this instruction.

For the past four decades, state bureaucracies in New Zealand have moved away from framing Maori as primitive and have gravitated toward culture as the useful category when planning how to govern a diverse population. ${ }^{8}$ This shift occurred in response to protest movements in New Zealand. New Zealand protest movements were influenced by civil rights movements in the United States, arguing for Brown Power and forming the Polynesian Panthers. Hauraki Greenland (1991) described how protesters adopted Fanon's notion of negritude to claim a panPolynesian alliance. Viewing Maori and Pacific Islanders as equally "black" was still a popular way to express shared political interests while I 
was doing fieldwork. But I also heard people use kinship or host metaphors to describe these connections? Samoans are the older brothers of Maori, or the guests of Maori.

In response to these social movements, the New Zealand government began to support local Maori communities financially to provide their own social services, providing grants for Maori language nests and other culturally sensitive programs. ${ }^{9}$ Seen by the government as culturally similar to the Maori, Pacific Islanders also began to have access to similar support for various community social services. In addition, the government began to fund competitive cultural festivals. ${ }^{10}$

Since the late 1920s, Maori cultural groups have been performing kapa haka in noncompetitive, paid public performances that toured the nation. Maori haka competitions, which some Maori leaders thought were not traditional, started at almost the same time (Kaiwai \& ZemkeWhite, 2004). The first government-sponsored National Polynesian Festival occurred in 1972 (for a historical overview of this festival, see Richards and Ryan 2004). This was not the high school festival, which began in 1976 under Hillary College's auspices. What traces are left in the letters and one slender newsletter held in the New Zealand National Archives suggests that the first National Polynesian Festival established an organizational tension that would continue until 1997, and beyond. The organizers for this first festival had a bit of difficulty figuring out how best to showcase the cultural diversity of Polynesians, which they were committed to celebrating. The organizers were primarily Maori, with one sole Samoan voice representing the Pacific Islanders, Reverend Sio. Ironically, much to the dismay of various Pacific Island coordinators, the 1997 festival also had only one representative of Pacific Islanders on the organizing committee-a Samoan. ${ }^{11}$ In the first National Polynesian Festival, Rev. Sio didn't have quite as many groups to represent as the sole Samoan voice had in 1997. He protected the interests of two Cook Island performing troupes, two Samoan, one Tokelauan, and probably one Niuean. These were noncompetitive groups, unlike the Maori cultural groups. Those identifying as Maori began a struggle over the organization of the judges, and who or what they judge, which still occurs. The noncompetitive spirit among those not identifying as Maori was not going to last. By 1976, when a teacher at Hillary College decided to organize a high school festival, non-Maori groups in the six participating schools were enthusiastically competitive.

Three aspects of the first festival have been repeated in every festival since. First, from the earliest recorded discussion of cultural groups, not all group members identified themselves in terms of the same cultural identity. ${ }^{12}$ In the 1972 Polynesian festival, the organizing committee 
attempted to find time slots for the several Pacific Island groups that had Maori members. And in 1997, at least 7 of the competitive Samoan groups out of the 37 groups competing had members who did not identify as Samoan, but rather as Tongans, Indians, Anglo-New Zealanders, and most likely others as well. Among the Maori groups, ethnicity does not determine one's location on stage. Among the Samoan groups, it was less likely that Anglo-New Zealanders would be in the front row. I did not see a single Anglo-New Zealand in an important leadership role. One teacher engaged in the project of being Samoan told me that although Anglo-New Zealanders could participate, they would never be as good as a Samoan, and continued to say that the differences between New Zealand-raised Samoans and Samoan-raised Samoans were also quite noticeable in these performances. This staging reflects a particular relationship to knowledge and skill that underpins many of the ways that people engaged in the project of being Samoan attribute symbolic capital to each other (see Gershon, in press). People engaged in the project of being Maori do not share the same beliefs in how knowledge is shared and distributed and will also have people who do not self-identify as Maori in prominent frontline positions or even as leaders in cultural groups.

Second, the way that the festival has been funded has followed similar patterns over the years. In the first festival, the Maori Purpose Funding Board (a nongovernmental organization) contributed the majority of the financial backing: $\$ 8,500$. The remaining $\$ 1,500$ was donated by the Ministry of Island Affairs, out of a general fund for helping Pacific Islanders in New Zealand. The government has been supporting the festivals quite regularly since; Creative New Zealand, a government agency, contributed $\$ 29,000$ to the 1997 festival under discussion. Since 1985, ASB Bank has been involved, a move that coincides with its companywide decision to provide financial backing for high-profile community activities. Other sponsors, who don't contribute enough to get name recognition in the actual festival name, are Coca-Cola, Tip Top Ice Cream, and Pacific Corned Beef. Clearly, supporting song and dance tickles the fancy of more than one goose with a golden egg to lay and has done so through several governments and financial cycles.

Third, the festival has been competitive from its inception. This presupposes that it is possible to judge what might be the best performances in the first place ${ }^{13}$ There are certain assumptions held by people participating in the competition about the categories of these traditional performances that can transform them into judgeable events. ${ }^{14}$ Various elements of the performance are quantifiable; the judges are expected to transform their perceptions and evaluations into numbers that can be 
collated and computed (see Bowker \& Star 1998; Hacking, 1990). From the uniform to the uniformity, all can be transformed into quantities. This style of quantification affects the final result. The best overall group is determined by adding its cumulative score from all the categories. A group needs to be in the top three groups of most categories to be the overall winner of their cultural category ${ }^{15}$ The best Samoan group is a composite of other evaluations, not the product of the judges' general consensus. This modus operandi is even true in terms of how the groups from different cultures have faired vis-à-vis each other. The total number of points that a particular group is awarded can then be compared with the other ethnic groups unofficially by audience members for a festivalwide comparison. In short, the large decisions are always already the numerical consequence of many small decisions by judges on how to transform various actions into numbers.

Behind the numbers is the assumption of a standard. There is a correct way to perform each item, and the audience watches attentively for a mistake. People have varying stories of where this standard comes from, although most link the standards to so-called traditional authority. People engaged in the project of being Samoan often located expertise in Samoa. Samoan-raised children were described as skilled performers, whereas New Zealand-raised children were viewed as not so swift, not so adept. One telling rumor involved De La Salle, an all-boys' school that frequently had been one of the top three groups. The De La Salle cultural group had a reputation as the source of most creative moves (since around 1989). To explain this creativity, many people not associated with De La Salle told me that the group sent its leaders over to Samoa every year to learn the latest moves. ${ }^{16}$ This is but one of the moments in which Samoa figured as the source of all great performances, with Samoans in New Zealand offering only pale imitations. The standard that the judges, all of whom were born and raised in Samoa, use is of an ideal that is imagined to exist in Samoa. This causes an uneasy tension surrounding how one evaluates innovations. The group I observed rehearses daringly introduced musical phrases from Michael Jackson's song "Thriller," presenting a challenge to the judges. The canon for the Samoan cultural groups is imagined with a geographical location that they are recreating from their homeland, ${ }^{17}$ and the judges' ostensible aim is to evaluate approximations to this metaphorical embodiment of Tradition.

The funders saw the festival as a celebration of controllable diversity; everyone was different, but the difference was carefully regulated along the same lines. Debby Bell, ASB's events marketing manager, said, "This is a festival where we can share in each other's diversity. It is an expression of New Zealand's many cultures reflecting the colorful, vibrant and 
exciting nation we all live in together." The many cultures that Debby Bell extols express their diversity through different dance forms, different songs, and different foods. This was a celebration of a quite restricted form of multiculturalism: a homogenous heterogeneity. The funders were ideologically committed to supporting diversity, but this support should in no way come at the expense of individual rights or state authority. What they are funding, in fact, is the idea that every culture has a similar relationship to a standardized repertoire of creative expression. From this perspective, to have a culture, one must have songs, dances, foodall items that are uniquely styled but still recognizable. Differences are tolerated or even encouraged, but in practice, these differences must all be structured in the same nondisruptive way. From a funder's perspective, although heterogeneity can be acceptable, differences must lie in the details of the performances, not the underlying premises or the act of performance itself. The cultural diversity celebrated presumes erroneously that all these groups share a common relationship to heritage, to tradition, to identity, but one that they manifest in different styles.

\section{PERFORMING BEING MAORI}

I turn now to a discussion of Maori cultural groups, relying on fieldwork conducted by Elisabetta Carusi. The current form of kapa haka performances largely derive from Maori concert parties in the 1920s and 1930s. Maori concert groups would tour New Zealand and occasionally perform abroad, performing three types of Maori dance: haka, action-song, and poi. Although other forms of dance genres exist, these types have become the backbone of Maori competitions (Shennan \& McLean, 1979). In many public arenas, haka performances have become iconic of Maori cultural identity, but as David Murray (2000) noted, haka performances are also multiple signifiers. In discussing the moment in conversation when haka stands for Maoriness, he wrote, "However, in the course of subsequent conversations, most of the Maori-identified speakers would shift to discussing how hakas could be representative of other collectivities as well, be they tribal, sub-tribal or team-based" (p. 348). Kapa haka can stand for allegiances at many different levels of scale, providing a medium for thinking through the different levels' constraints for embodying group unity.

As a result of the Maori renaissance, kapa haka has undergone a shift in its role as signifier in New Zealand's political terrain. In 1979, a widely publicized protest against Auckland engineering students' annual mockery of the haka focused attention on Maori grievances against Anglo-New Zealanders' symbolic degradation of their cultural identity. In prior years, 
Auckland University's engineering students had performed an inept and mocking haka to which Maori students took great offense. The student organization had received complaints and criticism, yet continually chose to ignore this dissatisfaction. Finally, in 1979, a group of Maori and Pacific Island students choose to express their disapproval quite forcibly, disrupting a morning rehearsal. This quickly captured the media's attention and, for a while, this incident served as a vehicle for talking about the symbolic violence that Maori have been facing in quite a number of arenas (Hazlehurst, 1988). The New Zealand public felt historical twinges from this old wound when the Spice Girls parodied the haka just before the 1997 festival. The ensuing disgruntlement was a clear reminder that kapa haka had lost its parodible innocence over a decade ago and was occupying a sacrosanct status in New Zealand's public spheres.

Performances on the Maori stage at these high school festivals have become forums for performers to tell audience members how to be better both at being indigenous and at being respectfully bicultural from a youth's perspective. One Maori haka at the festival that also received popular press coverage was Manurewa High School's haka encouraging young Maori to reject suicide. Topics ranged from calling for a great commitment and support to Maori language to commenting on inadequate housing and drug abuse. Both the Maori speeches and the songs performed at the high school festival have become relatively accessible forums for youth protest, offering an arena for public commentary that has formerly been reserved for elders.

Elisabetta Carusi observed the high school group Manutaki, the winners of the 1997 Maori section, prepare for the festival. The Manutaki cultural group was from a Maori school attached to Ioani Waititi, an urban marae ${ }^{18}$ in Auckland. This school was the first in New Zealand to have a curriculum all in Maori from preschool to the end of high school. ${ }^{19}$ Part of attending this school involved practicing Maori songs and haka throughout the year. The actual amount of time that this cultural group rehearsed for this specific festival makes a mockery out of Lange's critique; they only rehearsed for three weekends. This is certainly not the case for other cultural groups, be they Maori, Cook Island, Tongan, Niuean, or Samoan. They rehearsed a comparatively brief amount of time because in some form or another, they were constantly practicing. Although the particular lyrics of the songs or the sequence of dance movements might be specific to this festival, they were continually practicing the techniques underlying this performance. For example, they often practiced lining up in rows so that everyone is equidistant from each other. This can be unexpectedly difficult. Yet the students were 
so familiar with this that they did it with ease, and unprompted by their leaders. In other cultural groups, leaders of the group were constantly pointing out performers' failure to do this. The short time frame for actual rehearsal was a distinctive element for this cultural group.

In general, the Maori cultural groups did not have an age-dependent hierarchy differentiating who teaches and who learns. Everyone participates in rehearsing a particular item, no matter how old or experienced. Beginners practice in the same group as people who have spent years rehearsing a particular skill, and 10-year-olds stand next to 45-year-olds without inspiring any comments. Each person performs according to his or her own ability in rehearsal. The public evaluation of skill (and occasionally perceived attractiveness) occurs only when the leaders select who will be in the front line and who in the back. Then, and only then, are people explicitly selected to please the judges, undercutting the rehearsal ethos of equality.

Cultural groups have become a space in which people can teach others about the counterpoint to the hierarchy of knowledge and expertise displayed in other moments on the marae. ${ }^{20}$ They are taught that all have the potential to be skillful, that all can be valued members of the cultural group or of the marae. On the level of student, all are superficially interchangeable, irrespective of their particular historical trajectories or depth of experience with these forms of expression. It is in these moments that the assertion of group unity appears to supersede exploring the intricate social relationships inflected by different people's involvement with their Maori identity. Evincing groupness occurs during rehearsals through the practices in which people present and perform skills, and in the actual performance itself.

One of the important functions of the kapa haka group on this marae is to introduce people to the cultural nuances of being Maori. Many people who identify themselves as urban Maori were introduced to what they consider to be Maori culture through dance. For the Maori renaissance to flourish, people must hold that culture is learned and learnable. People who identify as urban Maori often felt alienated from their cultural backgrounds, a sense of dislocation that urban marae were supposed to remedy. The Maori's historical relationships have made cultural loss a constant dilemma, one that encourages them to treat cultural knowledge as learnable and cultural skill as acquirable.

Not all Maori social organization is based on performing egalitarian relations. Many other moments on a marae involve navigating complex hierarchical relationships; the equality practiced in rehearsals is implicitly being juxtaposed with other hierarchical relations. And this equality is a vehicle for people to realize that they can all be Maori together, that 
there are moments in which being Maori supersedes any number of complex internal divisions. In these moments of civil society, Maori students are learning a group unity premised on an equality that anticipates the gaze of the nation. Maori students in these rehearsals practice an equality that they will turn around and request of the nation in their performances. The equality practiced in rehearsal becomes the equality preached on stage.

\section{PERFORMING BEING SAMOAN}

I turn now to the Kelston Boys Samoan cultural group that my colleague, Solonaima Collins, and I watched as they practiced for 6 weeks, preparing to perform at the festival for 20 minutes. Through church and various mutual acquaintances and friends, both Solonaima Collins and I knew the Samoan-identified college teacher who was in charge of this allboys cultural group. He graciously allowed us to attend rehearsals. For the most part, we were able to attend at least two rehearsals a week. In addition, we interviewed various other people involved in the festival, including those who had been extensively involved with two of the three schools that have won over the past 5 years, Auckland Girls Grammar and De La Salle.

The Kelston Boys had students ranging from third form to seventh form (roughly ages 12-18) participating in the group. These students were required to choose an after-school activity and decided to join the Samoan cultural group instead of several other sport options. Although some of the boys had been involved in the Samoan cultural group for a number of years, for the most part, the group was filled with a higher proportion of newcomers than in previous years. People left the cultural group for a number of reasons; often, participants graduated or chose other options. In one instance, one of the stronger members of the group had been expelled from Kelston Boys College and was competing in another college's cultural group.

The students in the cultural group often had complicated reputations in the school. Several teachers told us that some of the best students in these cultural groups, ones who were quite disciplined and also were very good leaders, did not fit in well in the classroom environment. In class, they were disruptive and were perceived as discipline problems. Yet in the cultural groups, they excelled. In fact, the Kelston teacher pointed out a student leader in the first rehearsal that I attended and told me that other teachers in the school had been initially concerned that he might be given such an important leadership position because he was such a troublemaker. He went on to say that this student was one of the best 
leaders and worked hard to maintain a high level of discipline within the group. From the beginning, we were given strong indications that the systems in which authority was distributed and how knowledge transmission was performed might be different in Samoan cultural groups and in the student's daily classroom experiences (see Jones, 1991, for a similar argument for an Auckland girl's school).

Whereas Maori cultural groups? rehearsals practiced a form of equality, Samoan group rehearsals rendered hierarchy concrete. There is a teacher, typically (although not necessarily) perceived as Samoan, who supervises the group. Every teacher I interviewed stressed that the students in their group do all the work; the teachers don't teach the students what to do. They insisted that students make all the creative decisions. For the most part, the teacher is there to liaison with the school administration and be the final disciplinary authority. Teachers negotiate with the school administration to arrange overnight practice on the school grounds, help organize the uniforms, arrange transport from the school to the festival, and often act as the final authority in group disputes. The teachers are normally present at all the practices, but they are not actively teaching or participating.

Although this is by far the most common situation for the cultural group, there is a quite frequent exception. Occasionally the teacher's role is fused with a tutor's role. This was certainly the case in one of the other cultural groups I observed briefly. This all-girls cultural group had an adult leader who was not actually a teacher at their college. Instead, he attended a local teachers' training college. He, like others in similar positions, was under 30 and was not yet established in his profession. Yet, unlike the tutors, who I will discuss in a moment, he had no prior affiliation with the school's cultural group. His role was markedly different in yet another way: He composed all the songs and dances that the group performed. For the most part, the teachers were not the creative impetus behind the group. Their main function was to make sure that organizational aspects ran smoothly and provide the authority figure necessary to reassure the school administration.

The students themselves then divided up into two ranks of leadership: tutors and leaders. The tutors were former students at Kelston Boys who had been leaders of the group in previous years but had left school within the past couple of years. They would return to coach the group and often participated quite actively in the creative process. Among the Kelston Boys, the tutors were often students whom the teacher specifically asked back, although sometimes these former students voluntarily offered their time. Their input was welcome, and their creative judgments and discipline were invariably deferred to. 
The leaders were students who had not yet left school and typically were seventh formers who had been in the cultural group for a number of years. The three of them were always at rehearsal, teaching the boys the new steps, drumming on overturned rubbish bins or stools to keep the beat. They also disciplined by assigning push-ups, and using steely glances and generalized put-downs such as, "You all look like a bunch of pooftahs" or "Are you Kelston Boys or Kelston Girls College?" The teacher at Kelston Boys College saw himself as carefully grooming likely leaders and molding the cadre of boys into their leadership roles through judiciously applied personal attention. When I asked him how he chose who was going to be the next leader, he said that he would select the ones who came to him with original ideas for how various items could be performed. He would then start taking them aside and encouraging them to become leaders next year and implement their ideas. The students themselves did not see the process as conscious or deliberate in the way that the teacher described. The leaders didn't perform in the cultural group, although often one will take the place of the taupou (a girl of high rank and soloist dancer) or, in the case of the Kelston Boys, the manaia (a boy of high rank) and the fuataimi. They choreograph the dances, teach the songs, do the majority of the disciplining, and in general do the daily work of fashioning unruly students into a cohesive and proud group at the festival. To sum up, the teachers were most frequently not responsible for the actual content presented; the students were teaching each other the songs and dances. The leaders were principally the ones who had the creative spark, who choreographed all the moves and decided on the lyrics. They would have strong input from the tutors, the former students, but the inspiration was, for the most part, theirs. Students who participated in these activities learned an important political lesson: They could watch or be part of a hierarchy that shifted from year to year and included promotion for those who had served the group well in previous years.

This hierarchy affected both the strategies for knowledge transmission and discipline. There were two basic strategies for teaching a 30-second segment of dancing. No one showed the group the entire item before teaching them all the different segments. Instead, every day or so they would be taught a new segment and rehearse what they had already learned. In part, this was because the leaders and tutors did not know in advance what the whole item would look like. Instead, they invented the item bit by bit, often a few hours before teaching the group. Two strategies were used to teach the new additions. These strategies were often used simultaneously by the Kelston Boys group; half the group would be outside being taught in one way, the other would be on the stage of the 
auditorium being taught in another way. Those on stage would be shown the sequence, and then as a group of 10 or 15 , they would start practicing. They would divide up into rows, and each row would practice the sequence together occasionally. But for the most part, most were taught while the large group was away.

Outside, the students would be divided up into small groups. The leader would demonstrate the moves three or four times, and then he would join one of the small groups as they practiced it. He would practice alongside two or three students and keep murmuring encouragement. Then he would have them practice a few times on their own. Occasionally he would have a more experienced student, one who understood how to do the sequence, join a small group that was having problems. They would then practice a couple of times. This seemed much more effective, because students would start performing sequences smoothly after 10-20 minutes, whereas the other larger group of students took 30 minutes to an hour to perform their sequences smoothly.

The students themselves also frequently adopted this small-group approach to learning. When I walked into the auditorium for the first time, what immediately struck me was that even as the teacher was calling roll, the boys were surreptitiously practicing various sequences. Whenever there was a break, they would move into smaller groups of 2 or 3 , a beginner learning from one who was a bit more advanced. Most of the actual teaching in these groups occurred between students who were slightly more advanced passing down the knowledge-a trickle-down approach to teaching.

However, the people leading the cultural groups actively discouraged this informal form of teaching. One of the leaders in particular would try to prevent these moments. We were frequently hearing him yell, "Fold your legs-are you Samoan? There will be plenty of time for that during practice." He was constantly trying to get them to be still and orderly during roll call and at other times. This form of learning appears chaotic when the aim is to create synchronized movements. Thus, the leader tried to impose the ultimate goal of a synchronized, orderly, and disciplined group appearance from the early rehearsal sessions.

Patterns of verbal discipline revealed and reinforced the group's hierarchy. When Solo Collins and I collated exactly who disciplined whom, and with what language, we began to notice a striking pattern. The teacher had primarily two techniques. He largely singled out individuals by name and told them that they were not doing something properly. Toward the end of practice, he would focus on one person and yell, "Hey, Leo, stop fooling around." Although his main intervention during the actual practice involved paying attention to individuals, he would also 
scold the group as a whole with various threats of embarrassing themselves. He would tell them how little time they had and how they would shame themselves if they continued practicing this way on the day of the festival, and occasionally he would tell them that they didn't want to look stupid in front of the palagi (Samoan for White person), meaning me.

The tutors and leaders were quite similar in the way they disciplined. They almost never pointed out that a single person was misbehaving or had not learned something properly. The tutors would choose 2 or 3 students and tell them to do 10 push-ups, with the group watching and teasing them in the background. The leaders were often even more circumspect and would select an entire row to criticize. They never gave a particular name but would say, "You guys better stop fooling around." When an individual was doing a move incorrectly, the leaders would have the entire row repeat the sequence over and over. In other words, the more senior the person was, the more likely he or she was to individuate when disciplining.

I have been discussing intragenerational teaching up to this point. In general, the students received instructions from people who are just a little bit older or just a little bit more experienced. ${ }^{21}$ For the most part, group dances fit this pattern of teaching. Solo performances, however, were taught across generations. Solo dancers such as the taupou or manaia received guidance on how to dance from a much older relative-a grandmother, aunt, mother, or even a much older sister with a reputation among their extended family for dancing particularly well. The roles that were individuated were also often described as ones in which people display their skill or knowledge of so-called traditional Samoan culture. Students were selected for these roles based on their perceived family links to Samoa and cultural knowledge. The roles taught across generations are also the ones for which traditional expertise with the language and movements was described as the most crucial. Although in other items, the group walked a fine line between innovation and tradition, the taupou or manaia were never supposed to be innovative. ${ }^{22}$ For the most part, intergenerational learning underpinned the roles that tolerated the least innovation.

Whereas Maori performances were forums in which people could present themselves as indigenous critics of the nation, Samoan performances were forums for expressing migrant nostalgia. In 1997, the theme was Samoa: Past, Present, and Future. Not surprisingly, the songs had strong undertones of nostalgic nationalism. The overall winner played heavily on this. This all-girls group held the flag of Samoa as a screen for a girl's machete-twirling performance while the group filed in behind the flag. Many of these students have never been to Samoa, or 
only for short periods. The references to Samoa for them were intimately connected to a homeland created by family stories and gestures of remembrance. They see Samoa dimly through the photographs, videotapes, and visitors' stories. As I discussed earlier, in terms of the festival, Samoa has become the source of tradition, the source of canonical knowledge. The songs themselves are invariably about Samoa, coupled with comments on other schools or the students' earnest promises to be good children. They never have the explicit political messages of the Maori songs and oratory. The songs are about creating a particular relationship to Samoa, and the songs teach their audience how to be nostalgic.

At the heart of this plea that the audience members long for a Samoa that all have heard of but not so many have visited is a plea for a stability at the heart of migrant nostalgia. Members of cultural groups are constantly telling each other and their audience that steadfast relationships to a supposedly stable and presumably traditional social order should be longed for. This pedagogical exercise in nostalgia is expressed not only through the songs but also in the rehearsals and rumors circulating around the rehearsals. Intriguingly, this longing for such stability must be taught over and over again; these performances teach what is the proper relationship to being in New Zealand-feeling displaced, and the proper relationship to Samoa-longing. My interlocutors would suggest that this constant need is produced by the ever-present threat of the alternative and enticing New Zealand way of living. Perhaps, however, this is not a form of instruction whose need is inspired by the exigencies of migration, as my interlocutors would claim, but rather a pedagogy necessitated by people's tendencies not to do what they are told, as Varenne (2007) suggests. ${ }^{23}$

\section{CONCLUSION}

In this article, I have taken rehearsing and performing in the ASB cultural festival as a site for exploring ethnographically how people participate in civil society. In doing so, I have been exploring how festival participants exercise their anthropological imagination; by this, I mean when and how people involved in the festival frame differences as cultural in civil society contexts. This is an ethnographic investigation of how the politics of recognition is practiced and performed in educational contexts. The festival provides a space for migrants and indigenes to express their reservations about the democratic commitments that the New Zealand nation offers. People are constantly telling each other to feel ambivalence, or even disaffection, in anticipation of the double- 
edged sword of the nation's recognition. While rehearsing and performing, people are discussing the implications of belonging to a nation at the same time that they are acutely aware that, in the very moment of participating in civil society, they reveal themselves to be foreign bodies. Recognition in this festival context thus is a moment in which a particular form of belonging and otherness is expressed simultaneously.

I have focused on how members of the Maori cultural group teach what it means to be an indigenous citizen, as opposed to how members of the Samoan cultural group teach what it means to be a migrant citizen. Those in the Maori cultural group teach that tradition can become a political forum for commenting on the nation. The tutors teach the Maori cultural group that being a cultural performer is simultaneously also being an indigenous critic of the nation. Whereas Maori students in the cultural festival critique New Zealand head-on in their performances, Samoan students critique obliquely by proclaiming the ways in which they belong to another nation altogether. All those in charge of the Samoan cultural group teach that they belong to a Samoan nation, not the New Zealand nation, through a complex displacement of hierarchical nostalgia. To answer the article's initial question of how people actually engage with the political while in civil society, in this case, the students from both cultures are told to want other nations and other relationships to political orders.

The cultural festival stages can be described as arenas in which the nation and one's relationship to the nation is written in bold, clear strokes. Maori injustice and Samoan nostalgia are neatly delineated stances to take, proclaiming respectively a temporal and spatial distance from the New Zealand nation. The performers on the Maori stage are proleptic in their instructions, calling forth a future that does not include the inequalities of the present. The performers on the Samoan stage speak to the spatial divide that allows a stronger commitment to an elusive Samoa than to a present-day New Zealand context. Yet the performers' success in prescribing dislocations from their surrounding national contexts is a fleeting one. Once the festival is over, the performers will rejoin social contexts in which they must tell others what to do anew, and not always with such easily adopted scripts of tradition in the guise of already-defined other ways, times, and spaces.

Solonaima Collins, Elisabetta Carusi, and I were a fieldwork team in 1997, observing two different cultural groups preparing for the festival. I want to thank Elisabetta Carusi, whose fieldwork experiences among Maori cultural groups provided such rich ethnographic material for this article. Shari Kornelly and members of the ASAONET list server were very helpful in providing references and possible directions. I also want to thank Hervé Varenne-his determination, insightful interventions, and support were crucial to my umiting. The Kelston Boys cultural group and their teacher were kind enough 
to let Solonaima Collins and me observe their rehearsals and performances. The first version of this article was given in the University of Auckland's 1997 colloquium series. A Spencer Foundation grant made this research possible.

\section{Notes}

1 For an academic critique of such a perspective, see Manu`atu and Kipa 2002.

2 A week before the New Zealand Herald printed Lange's attack on the festival, an Auckland Pacific Island radio station presented a call-in show with a similar theme. The chat show devoted an entire hour and a half to discussing whether the secondary schools' festival was detrimental to children's education. Many Samoan parents called into the show, expressing similar concerns that children were wasting enormous amounts of time that should be devoted to their studies. David Lange was voicing a position presupposing a specific type of tension between tradition and modernity that was emerging in other public venues as well.

3 See Nina Eliasoph's Avoiding Politics: How Americans Produce Apathy in Their Everyday Life (1998) for a thoughtful ethnographic exploration of this question in the United States.

4 See Brackette Williams (1990) for an account of how different ethnic groups' historical relationships to the Guyanese nation shapes people's participation in a festival.

5 See Manu'atu (2000) for a discussion of Tongan cultural groups participating in Auckland's secondary school cultural festival. For other explorations of the intersection between festivals, performances and nationalism, see Furniss 1998; Henry 2000; and Reed 1998.

6 For a parallel study of how Lei Day in Hawai'i was a historical attempt to respond to a multicultural population, see Friesen (1996).

7 Anthropologists will use the phrase cultural group quite broadly; I am not. In this article, cultural group only refers to a high school team that performs in the festival.

8 For some critical explorations of ways the culture concept is being deployed in New Zealand, see Goldsmith 2003; Sissons 1993; Webster 1998.

9 In 1944, the Department of Maori Affairs established a social welfare division, one that was geared toward assisting Maori to assimilate into urban Anglo-New Zealand lifestyles. This policy shifted dramatically in the late 1970s. Maori and Pacific Islander activism contributed to the national government's decision in 1977 to launch "Tu Tangata," which was essentially a shift in Maori affairs policy. According to Fleras and Spoonley (1999), "Tu Tangata promised to invert the bureaucratic pyramid through the creation of community-driven, culturally sensitive programs and services" (p. 116). With this policy, the government began to remedy the affects of earlier assimilationist policies which had only served to worsen Maori social and economic status.

10 There is a tradition of promoting festivals to encourage people to contemplate their commitments to the nation in the Pacific. Jeffrey Sissons (1999) has an engaging historical overview of how government officials sponsored competitive festivals as a way to encourage a sense of national identity in the Cook Islands.

11 This singular representation did not go down too well, and there was, as there has been for the past several years, quite a bit of murmuring about splitting the secondary school festival in two: one festival devoted solely to Maori, and one devoted to all others.

12 James Ritchie, in Becoming Bicultural (1992), talked about how going to dances and then joining a cultural group in 1945 was his first powerful introduction to Maori com- 
munities. He wrote, "Thus my entry into the Maori world was not with my head and my heart but with my hips" (p. 14).

13 Not all New Zealand school festivals are competitive; for example, the Wellington cultural festival is not.

14 In practice, these evaluations are quite contentious, with many rumors of injustice surrounding these decisions.

15 Since my fieldwork, the Samoan overall winners have become divided by gender. Now there are three overall winners: the top group from an all-girls' school, an all-boys' school, and a coed school.

16 When I asked a former De La Salle member about this, he was very clear that this had never been true.

17 See Duranti (1997) for further discussion of how migrants use spatial placement to create nostalgic links to Samoa.

18 A marae is a sacred Maori meeting house. As the New Zealand government began to encourage Maori culture to flourish, the Department of Maori Affairs began funding urban community centers, or urban marae. Daniel Rosenblatt (2003) has written an engaging dissertation on the Hoani Waititi marae, where Elisabetta Carusi did her research.

19 For a historical overview of how Maori language education became a symbol of how to produce a bicultural nation, see Doerr (2004).

20 For an account of the ways in which the failure to teach others songs reveals the dynamics behind complex Maori hierarchies, see McLean 1965.

21 Alison Jones (1991) discussed how frequently Pacific Island girls teach each other in New Zealand classrooms, to the occasional dismay of their adult teachers.

22 The fuataimi was an exception because he or she is expected to clown and thus is allowed to be more original.

23 See Gershon (2000) for an outline of why nostalgia for Samoa might be in some people's best interests.

\section{References}

Bowker, G. G., \& Star, S. L. (1998). Sorting things out: Classification and its consequences. Cambridge, MA: MIT Press.

Doerr, N. (2004). Desired division, disavowed division: An analysis of the labeling of the bilingual unit as separatist in an Aotearoa/New Zealand school. Anthropology and Education Quarterly, 35, 233-253.

Duranti, A. (1997). Indexical speech across Samoan communities. American Anthropologist, 99, 342-354.

Eliasoph, N. (1998). Avoiding politics: How Americans produce apathy in everyday life. Cambridge, England: Cambridge University Press.

Fleras, A., \& Spoonley, P. (1999). Recalling Aotearoa: Indigenous politics and ethnic relations in New Zealand. Auckland, New Zealand: Oxford University Press.

Friesen, S. (1996). The Origins of Lei Day: Festivity and the construction of ethnicity in the Territory of Hawai'i. History and Anthropology, 10, 1-36.

Furniss, E. (1998). Cultural performance as strategic essentials: Negotiating Indianness in a Western Canadian rodeo festival. Humanities Research, 3, 23-40.

Gershon, I. (2000). How to know when not to know: Strategic ignorance when eliciting for Samoan migrant exchanges. Social Analysis, 44, 84-105. 
Gershon, I. (in press). Compelling culture: The rhetoric of assimilation among Samoan migrants in the United States. Ethnic and Racial Studies.

Goldsmith, M. (2003). Culture, for and against: Patterns of "culturespeak" in New Zealand. Journal of Polynesian Society, 112, 280-294.

Greenland, H. (1991). Maori ethnicity as ideology. In P. Spoonley, D. Pearson, \& C. Macpherson (Eds.), Nga take: Ethnic relations and racism in Aotearoa/New Zealand (pp. 90-107). Palmerston North, New Zealand: Dunmore Press.

Habermas, J. (1989). The structural transformation of the public sphere. Cambridge, MA: MIT Press.

Hacking, I. (1990). The taming of chance. Cambridge, England: Cambridge University Press.

Handler, R. (1988). Nationalism and the politics of culture in Quebec. Madison: University of Wisconsin Press.

Hazlehurst, K. (1988). Racial conflict and resolution in New Zealand: The Haka Party Incident and its aftermath 1979-1980. Canberra: Peace Research Centre, Australian National University.

Hegel, G. (1967). Hegel's Philosophy of Right (T. M. Knox, Trans.). Oxford, England: Oxford University Press, 1967. (Original work published in 1821)

Henry, R. (2000). Festivals. In S. Kleinert \& M. Neale (Eds.), Oxford Companion to Aboriginal Art and Culture (pp. 586-587). Melbourne, Australia: Oxford University Press.

Jones, A. (1991). At school I've got a chance: Culture/privilege: Pacific Islands and Pakeha girls at school. Palmerston North, New Zealand: Dunmore Press.

Kaiwai, H., \& Zemke-White, K. (2004). Kapa Haka as a "web of cultural meanings." In C. Bell \& S. Matthewman (Eds.), Cultural studies in Aotearoa New Zealand (pp. 139-160). Oxford, England: Oxford University Press.

Labaree, D. (1997). How to succeed in school without really learning. New Haven, CT: Yale University Press.

Manu'atu, L. (2000). Pedagogical possibilities for Tongan students in New Zealand secondary schooling : Tuli ke ma u hono ngaahi malie. Doctoral dissertation, University of Auckland, Auckland, New Zealand.

Manu`atu, L., \& Kipa, M. (2002). A critical theory to TESOL: The promising focus for indigenous perspectives. Journal of Engaged Pedagogy, 2(1).

McLean, M. (1965). Song loss and social context among the New Zealand Maori. Ethnomusicology, 9, 296-304.

Murray, D. (2000). Haka fracas? The dialectics of identity in discussions of a contemporary Maori dance. Australian Journal of Anthropology, 11(3), 14-26.

Reed, S. A. (1998). The politics and poetics of dance. Annual Review of Anthropology, 27, 503-532.

Richards, P., \& Ryan, C. (2004). The Aotearoa traditional Maori performing arts festival 1972-2000: A case study of cultural event maturation. Journal of Tourism and Cultural Change, 2(2), 94-117.

Ritchie, J. (1992). Becoming bicultural. Wellington, New Zealand: Huia.

Rosenblatt, D. (2003). Houses and hopes: Urban marae and the indigenization of modernity in New Zealand. Doctoral dissertation, University of Chicago.

Shennan, J., \& McLean, M. (1979). Remarks on Youngerman's "Maori dancing since the eighteenth century." Ethnomusicology, 23, 492-499.

Sissons, J. (1993). The systematisation of tradition: Maori culture as a strategic resource. Oceania, 64(2), 97-117.

Sissons, J. (1999). Nation and destination: Creating Cook Islands history. Suva, Fiji: University of the South Pacific.

Taylor, C. (2002). Modern social imaginaries. Public Culture, 14(1), 91-124. 
Tocqueville, A. (2000). Democracy in America (G. Lawrence, Trans.). New York: Harper Perennial. (Original work published 1838)

Varenne, H. (2007). Difficult collective deliberations: Anthropological notes toward a theory of education. Teachers College Record, 109.

Williams, B. (1990). Traditionalism, cultural innovation, and the problem of cultural inauthenticity. In R. G. Fox (Ed.), Nationalist ideologies and the production of national cultures (pp. 112-129). Washington, DC: American Anthropological Association.

ILANA GERSHON is an assistant professor in communication and culture at Indiana University. She is interested in comparing Samoan migrants' experiences in New Zealand and the United States. Gershon is also the guest editor of "The Symbolic Capital of Ignorance" in Social Analysis and "Reflexivity in Others' Contexts" in Ethnos.

SOLONAIMA COLLINS is a recent graduate of Auckland University and is currently earning her master's degree in social work from University of Auckland. She is interested in comparing Samoan migrants' educational experiences in New Zealand and the United States. 


\section{COPYRIGHT INFORMATION}

TITLE: Outspoken Indigenes and Nostalgic Migrants: Maori and Samoan Educating Performances in an Aotearoa New Zealand Cultural Festival

SOURCE: Teach Coll Rec 109 no7 Jl 2007

The magazine publisher is the copyright holder of this article and it is reproduced with permission. Further reproduction of this article in violation of the copyright is prohibited. 